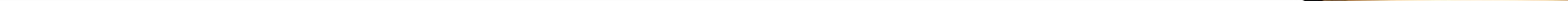




\section{Queer Theory and Brokeback Mountain}

\section{James Hodgson}

It almost goes without saying that as a body of scholarship queer theory is at once nebulous, polemic, at times impenetrable, politically daring, occasionally solipsistic. Thinking about what it means to be 'queer', work that at least officially began with Teresa de Lauretis' seminal conference in February 1990, now proliferates across the academy, and has travelled from its home in Lesbian and Gay Studies to fields as diverse as Science and Technology Studies, Organization Studies, and International Relations (De Lauretis, 1991; Rumens, 2013; Weber, 2016; Willey, 2016). Scholars continue to say novel, political, insightful things with its particular framing and find its theses on social norms, gender performativity, and later, on feeling, the future, homonationalism, and so on - to continually illuminate topics of contemporary life (Butler, 1990, Warner, 1993, Edelman, 2004; Puar, 2007, Ahmed, 2010; Halberstam, 2011;). Matthew Tinkcom's Queer Theory and Brokeback Mountain, published through Bloomsbury Academic, has the daunting task of providing an introduction to queer theory for readers unfamiliar with this sprawling, chimeric body of work, and offers an entry to the topic in an accessible-enough register for most undergraduate students. What makes Tinkcom's volume particularly useful is that it explains some key concepts in queer theory via the careful analysis of a single film, Ang Lee's Brokeback Mountain (Lee, 2005). Why film? Cinema, says Tinkcom, has been chosen over another form, say the novel, for straightforward reasons of accessibility. This makes sense - Brokeback Mountain is a groundbreaking cinematic exploration of same-sex love, a significant milestone in terms of recent LGBT politics, and also one of the most widely circulated films that deals with issues pertinent to queer theory.

The book is relatively short, at 125 pages, and divided into two chapters; the first provides a broad overview of queer theory and the second uses an extended analysis of Brokeback Mountain 
to exemplify some key queer ideas. The first chapter is a solid outline of the fundamentals. One of the book's strengths is the context that it provides - not only does it cogently set out Foucault's main talking points in The History of Sexuality, arguments many consider foundational to queer thought, but it also relays the debates to which Foucault contributed (namely, psychoanalysis and sexology), which together provide enough background for a newcomer to make sense of how and why the intervention of queer theory was significant at the time. Tinkcom also includes information on familiar queer figures, moving from Foucault to Eve Sedgwick, Gayle Rubin, and then on to Judith Butler. Whilst unpacking some of the more challenging ideas with lucid, accessible language, Tinkcom's book should also be commended for emphasizing how various strands of feminist thought informed queer theory.

The second chapter begins with a biopolitical reading of the film before introducing ideas about the closet, homosociality, and the performativity of masculinity and gender. Tinkcom's achievement in this chapter is the introduction of terms at a gradual pace with plenty of textual details to explain how, for example, the biopolitical arrangements of 1960s Midwest America interlace with the closet, or how compulsory heterosexuality shapes the protagonists' sexual and kinship behavior while providing the conditions for the articulation of same-sex desire. I got the sense Tinkcom was more interested in introducing the reader to queer theory as a way of thinking about the world - the book asks readers to pay attention to how systems of meaning and social structures shape desire and identity - and is far less focused on the nuance of arguments, say, around antinormativity, or the infamous so-called anti-social thesis (Edelman, 2004; Jagose, 2015). To my mind, that makes sense for an introductory text like this. But the book also includes an important consideration of whiteness, and a fascinating discussion of the film's reception by queer audiences in China, which updates the text in relation to recent scholarship on race and on world 
cinema (Amin, 2017; Eng, 2010; Ferguson, 2004; Schoonover \& Galt, 2016; Stokes, 2001) and begins to nuance queer work in ways that will be more familiar to informed audiences.

It's also worth pointing out that although Tinkcom is focused mostly on demonstrating the social and cultural construction of sexuality and gender he is ultimately using film as a lens to do so; the second chapter covers several important aspects of film analysis - genre, audience reception, and camerawork. The section on pastoral setting and the landscape is particularly compelling, and a sensible place to discuss the utopianism that characterizes some aspects of queer thinking. I might have liked some additional discussion of framing and mise-en-scène, but appreciate that a) the focus is on communicating the principles of the theory at hand and b) a wealth of excellent film scholarship already handles this (Bolton, 2011; Herring, 2007; Needham, 2010). As such, the book is strongly recommended both for students coming to queer scholarship for the first time, and to those in Media Studies, Film Studies and Cultural Studies interested in how contemporary thinking around sexuality and gender might be explored in a piece of relatively mainstream cinema.

Dr. James Hodgson

Postdoctoral Research Associate

University of Manchester

School of Social Sciences

Arthur Lewis Building

The University of Manchester

Oxford Road Manchester M13 9PL 


\section{BIBLIOGRAPHY}

Ahmed, S. (2010). The promise of happiness. Duke University Press.

Amin, K. (2017). Disturbing Attachments: Genet, Modern Pederasty, and Queer History. Duke University Press.

Bolton, M. (2011). The ethics of alterity: adapting queerness in Brokeback Mountain. Adaptation, $5(1), 35-56$.

Butler, J. (1990). Gender trouble and the subversion of identity. New York and London: Routledge.

De Lauretis, T. (1991). Queer theory: Lesbian and gay sexualities. Indiana Univ Pr.

Edelman, L. (2004). No future: Queer theory and the death drive. Duke University Press.

Eng, D. L. (2010). The feeling of kinship: Queer liberalism and the racialization of intimacy. Duke University Press.

Ferguson, R. A. (2004). Aberrations in black: Toward a queer of color critique. U of Minnesota Press.

Halberstam, J. (2011). The queer art of failure. Duke University Press.

Herring, S. (2007). Brokeback Mountain dossier: introduction. GLQ: A Journal of Lesbian and Gay Studies, 13(1), 93-94.

Jagose, A. (2015). The trouble with antinormativity. Differences, 26(1), 26-47.

Lee, Ang. (2005). Brokeback mountain. Focus Features.

Needham, G. (2010). Brokeback mountain. Edinburgh Univ Press.

Puar, J. K. (2007). Terrorist assemblages: Homonationalism in queer times. Duke University Press.

Rumens, N. (2013). Organisation studies: not nearly 'queer enough.' In Queer presences and absences (pp. 241-259). Springer. 
Schoonover, K., \& Galt, R. (2016). Queer Cinema in the World. Duke University Press.

Stokes, M. (2001). The color of sex: Whiteness, heterosexuality, and the fictions of white supremacy. Duke University Press.

Warner, M. (1993). Fear of a queer planet: Queer politics and social theory (Vol. 6). U of Minnesota Press.

Weber, C. (2016). Queer international relations: Sovereignty, sexuality and the will to knowledge. Oxford University Press.

Willey, A. (2016). Biopossibility: A queer feminist materialist science studies manifesto, with special reference to the question of monogamous behavior. Signs: Journal of Women in Culture and Society, 41(3), 553-577. 